\title{
Altmış Beş Yaş Üstü Metastatik Yumuşak Doku Sarkom Hastalarında Pazopanib Tedavisinin Etkinliğinin Retrospektif Değerlendirilmesi
}

\author{
Erdem ÇUBUKÇU, Birol OCAK
}

Bursa Uludağ Üniversitesi Tıp Fakültesi, Tıbbı Onkoloji Bilim Dalı, Bursa.

\begin{abstract}
ÖZET
Yumuşak doku sarkomları (YDS) mezenşimal hücrelerden köken alan tümörlerin nadir ve heterojen grububudur ve tüm erişkin kanserlerin yaklaşık \%1 ini oluşturmaktadır. YDS lerin 50 den fazla farklı histolojik tipi mevcuttur. Pazopanib, Vasküler endotelyal büyüme faktörü reseptör 1 (VEGFR-1), VEGFR-2, VEGFR-3, trombosit kökenli büyüme faktörü a (PDGFR-a) ve c-kit bloke eden oral kullanılan tirozin kinaz inhibitörüdür. İlerlemiş yumuşak doku sarkoması olan yaşlı hastalarda oral multi-tirozin kinaz anjiyogenez inhibitörü pazopanib ile tedavi sonuçlarını geriye dönük olarak inceledik. Medyan yaş 72 (65-79) olan toplam 13 hasta dosyası Ocak 2014-Eylül 2018 arasında retrospektif olarak incelendi. Kapesitabin ve Pazopanib tedavisi kemoterapi sonrasında progrese olan yumuşak doku sarkomlu yaşlı hastalarda etkili ve iyi tolere edilmiştir.
\end{abstract}

Anahtar Kelimeler: Sarkom. Vasküler endotelyal büyüme faktör reseptör. Anjiyogenez.

A Retrospective Evaluation of the Efficacy of Pazopanib Treatment in Patients with Metastatic Soft Tissue Sarcoma over 65 Years.

\begin{abstract}
Soft tissue sarcomas (STS) are a rare and heterogeneous group of tumors that originate from mesenchymal cells and account for $1 \%$ of all adult malignancies. STS is comprised of more than 50 different histological subtypes. The primary treatments of STS are surgery and radiotherapy. Pazopanib is an oral-used tyrosine kinase inhibitor that blocks vascular endothelial growth factor receptor 1 (VEGFR-1), VEGFR-2, VEGFR-3 platelet-derived growth factor receptor (PDGFR-a), PDGFR-a, and c-kit. We retrospectively reviewed outcomes of treatment with pazopanib, an oral multi-tyrosine kinase angiogenesis inhibitor, in oldest patients with advanced soft tissue sarcoma. A total of 13 patients with a median age of 72 (65-79) were evaluated retrospectively in between January 2014 and September 2018. Pazopanib therapy is effective and well tolerated in oldest patients with STS who had progressive disease after chemotherapy.
\end{abstract}

Key Words: Sarcoma. Vascular endothelial growth factor receptor. Angiogenesis.

Yumuşak doku sarkomları (YDS) mezenşimal hücrelerden köken alan tümörlerin heterojen bir grubunu oluşturmakta olup nadir görülen tümörlerdir'. Tüm kanserlerin yaklaşık \%1 ini oluşturmaktadır. YDS lerin 50 den fazla farklı histolojik tipi mevcuttur ${ }^{2,3}$. Bu tipler kendi içlerinde farklı klinik özellik taşımakta olup kullanılan tedaviler ve tedavi cevabi farklıdır. YDS li hastaların primer tedavisi cerrahi ve radyoterapi tedavisi oluşturmakta iken, hastaların \%5-30 lokal

Geliş Tarihi: 27 Aralık 2018

Kabul Tarihi: 06 Şubat 2019

Dr. Erdem ÇUBUKÇU

Bursa Uludağ Üniversitesi Tıp Fakültesi,

Tıbbı Onkoloji Bilim Dalı,

Bursa

Tel.: 05325245531

E-posta: erdemcubukculudag.edu.tr rekurrens ve \%10-38 i klinik olarak saptanabilen metastaz ile nüks etmektedirler ${ }^{4,5}$. Metastatik sarkomlarda klasik sitotoksik tedaviler ile medyan genel yaşam süreleri 12 aydan kısa iken son yıllarda sarkomların tiplendirilmesinin daha net ortaya konulabilmesi ve yeni tedavilerin kullanılması ile günümüzde medyan sağkalımlar 12 aydan daha uzun sürelere çıkabilmiş$\operatorname{tir}^{6,7,8,9}$.

Pazopanib, vasküler endotelyal büyüme faktörü reseptör 1 (VEGFR-1), VEGFR-2, VEGFR-3 trombosit kökenli büyüme faktörü a (PDGFR-a) PDGFR-a ve ckit bloke eden oral kullanılan tirozin kinaz inhibitörüdür ${ }^{10-12}$. İlk defa faz 2 bir çalış̧ma olan EORTC study 62043 ile yumuşak sarkomlu hastalarda etkinliği gösterilmiştir $^{13}$. Bugün pazopanib kemoterapi tedavisi ile progrese olan nonadipotik sarkom hastalarında standart tedavi olarak klavuzlarda yerini almıştır. 
Çalışmalar incelendiğin hastaların medyan yaşının 5055 olduğu görülmektedir. Çalışmalarda altmış beş yaş üstü hastalar ile ilgili veriler sınırlı sayıdadır. Bu çalışmada kliniğimizde ileri evre YDS nedeni ile pazopanib tedavisi uygulanan 65 yaş üstü hastalarda bu tedavinin etkinliği ve toksisitesi retrospektif olarak incelenmiştir.

\section{Gereç ve Yöntem}

Ocak 2014 ve Eylül 2018 tarihleri arasında Uludağ Üniversitesi Tıp Fakültesi'ne başvurmuş gemsitabin, siklofosfamıd, taxan, antrasiklin kemoterapileri sonrasında progresyon gelişen ve pazopanib ile tedavi edilen altmış beş yaş üstü nonadipotik sarkom hastalarının dosyaları retrospektif olarak incelendi.

Tedavide pazopanib dozu 80 mg/gün sabit doz devam11 olarak uygulandi. En az 2 aylık tedavi almış hastalar değerlendirilmeye alındı. Yan etki durumuna göre doz modifikasyonları yapılmıştır.

Yan etki ölçümleri ulusal kanser enstitüsü genel toksisite kriterleri skorlaması ile yapılmıştır. Hastalarda kardiyak değerlendirme tedavi önce yapılmış ve hastaların kardiyak fraksiyonları ekokardiyografi ile ölçülmüştür.

\section{Bulgular}

Ocak 2014 ve Eylül 2018 tarihleri arasında Uludağ Üniversitesi Tıp Fakültesi'ne başvurmuş ve YDS tanısı almış hastaların dosyaları retrospektif olarak tarand1. $\mathrm{Bu}$ hastalardan pazopanib tedavisi alan 32 hasta saptandı ve 65 yaş üstü hastaların dosyaları retrospektif olarak incelenmiş olup çalışmaya uygun 13 hasta saptandı. Hasta özellikleri Tablo I de gösterilmiştir. Çalışmada 8 kadın 5 erkek hasta saptanmış olup ortalama yaş 72 (65-79) olarak bulunmuştur. Tüm hastalar pazopanib tedvisi öncesinde 1 seri kemoterapi almışlardır. Kemoterapi altında progrese olan hastalarda tedavide pazopanib 800 mg gün dozunda kullanılmıştır.

Tablo I. Hasta genel özellikleri

\begin{tabular}{|ll|}
\hline Hasta sayısı(n) & 13 \\
Medyan yaş(ay) & $72(65-79)$ \\
Histoloji & \\
$\quad$ Leimyosarkom & $7(\% 53.8)$ \\
Undiferansiye pleomorfik sarkom & $3(\% 23)$ \\
Miksofibrosarkom & $2(\% 15.3)$ \\
Anjiosarkom & $1(\% 7.6)$ \\
\hline
\end{tabular}

Hastalarda komplet yanıt elde edilememiş olup, 5 hastada (\%38.4) parsiyel yanıt, 1 hastada (\%7.6) stabil hastalık elde edilirken, 7 hastada (\%54) progresif hastalık saptanmıştır. 1 hastada 2 yıl, 2 hastada 1 yılın üzerinde kullanım süresi mevcuttur. Tedavinin genel cevap oranları \%38.4 iken, klinik fayda oranı \%46 olarak bulunmuştur. Medyan genel yaşam süresi 12 (6.7-17.2) ay bulunmuştur. (Tablo II)

Tablo II. Tedavi cevap oranları

\begin{tabular}{|ll|}
\hline Yanıt oranları & \\
Komplet yanıt & 0 \\
Parsiyel yanıt & $5(\% 38.4)$ \\
Stabil hastalık & $1(\% 7.6)$ \\
Progresif hastalık & $7(\% 54)$ \\
\hline
\end{tabular}

Sıklıkla hastalarda diyare el ayak sendromu, iştahsızlık ve bulantı şikayetleri gözlenmiştir. Hematolojik toksisiteler daha az oranda gözlemlenmiştir. Tedavi ilişkili febril nötropeni ve tedavi ilişkili ölüm gözlenmemiştir. Diyare gelişen 1 hastada ve karaciğer enzim yüksekliği olan bir hastada tedaviye ara verilmiş olup şikayetler düzelince tedaviye pazopanib $600 \mathrm{mg}$ dozundan başlanılmıştır.

\section{Tartışma}

YDS lerin 50 den fazla farklı histolojik tipi mevcut olup bu tipler kendi içlerinde farklı klinik özellik taşımaktadır. Kullanılan tedaviler ve tedavi cevabı alt tiplere göre farklılık göstermektedir. Son y1llarda yeni sistemik kemoterapi tedavilere rağmen gastrointestinal stromal tümör dişındaki alt tiplerde belirgin başarı sağlanamamıştır ${ }^{14,15}$. Yeni sistemik kemoterapilerin sarkomlarda 2. ve daha sonraki basamaklarda kullanılmaya başlanılmasına rağmen genel yaşam süreleri 12 ay civarındadır. Gastrointestinal stromal tümör dışında ki alt tiplerde birinci basamak tedavide doksorubisin tek ajan yada ifosfamid ile kombine olarak yaygın olarak kullanılmaktadır. Bu ajanlar ile progresyon gelişen hastalara 2007 yılında trabectedinin bazı alt gruplarda kullanımı ile tedavi faydası gösterilmiştir. Yine angiosarkomlarda paklitaksel ve dosetaksel, leimyosarkomlarda ise gemsitabin ile dosetaksel kombinasyonları randomize olmayan çalışmalarda gerek genel sağkalım gerekse progresyona kadar geçen zamanda 1lımlı düzelmeler sağlamıştır ${ }^{15,16}$. Ayrıca gastrointestinal stromal tümörler ve dermatofibrosarkoma protuberans alt tiplerinde sunitinib ve imatinib gibi ajanların kullanılması ile yaşam sürelerinde belirgin düzelmeler sağlanmıştır ${ }^{17,18,21}$.

Çalışmamız retrospektif ve on üç hasta ile sınırlı olmasına rağmen yaşlı YDS hastalarında bir multikinaz inhibitörü olan pazopanibin etkinliğini ve tolere edilebilirliğini araştırmış olması nedeniyle literatüre katkıda bulunmaktadır. Literatür taraması yapıldığında yaşlı hastalar ile ilgili verilerin sunulduğu bir çalışma bulunmamaktadir. 


\section{Metastatik Yumuşak Doku Sarkom Hastalarında Pazopanib Tedavisi}

Kemoterapi sonrası progresyon gelişen metastatik YDS'Rli hastalarda pazopanib etkinliğini güvenliliğini gösteren en büyük çalışma 13 ülke ve 72 merkezde yapılan PALETTE çalışmasıdır. $\mathrm{Bu}$ çalışmaya 369 hasta dahil edilmiştir. Çalışma incelendiğinde medyan yaş 55 olarak saptanmıştır. Çalışmada prognostik faktörler ve progresyona kadar geçen süre (PFS) ile genel sağkalım süreleri (OS) arasındaki ilişki değerlendirilmiş olup bağımsız prognostik faktör olarak yaş 50 belirlenmiştir. Çalışmada elli yaş altı ve üstü incelendiğinde hem PFS hemde OS arasında istatiksel fark saptanmamıştır. Çalışmada PFS 4.6 ay, OS ise 12.5 ay olarak saptanmıştır. Çalışmamızda 65 yaş üstü hastalar değerlendirilmiş olup medyan genel sağkalım 12 ay olarak saptanmıştır. Sonuçlarımız incelendiğinde PALETTE çalışmasındaki hem 50 yaş altı hem de 50 yaş üstü hastalardaki sonuçlar ile benzerdir.

Kwai Han Yoo ve arkadaşlarının 43 hasta ile yaptıkları çalışmada medyan PFS 5 ay bulunmuş, genel sağkalım süresi 8.2 ay olarak saptanmıştır. Çalışmanın cevap oranlarına bakıldığında objektif cevap oran1 \%17.1 ve hastalık stabilizasyon oranı \%61 olarak bulunmuştur. Medyan yaş 54 olarak bulunmuş olup alt grup analizi incelendiğinde yaştan bağımsız olarak genç ve yaşlı hastalar arasında fark saptanmamıştır ${ }^{19}$. Çalışmamız ile karşılaştırıldığında cevap oranlarımız, OS ve PFS oranları nümerik olarak daha iyi olarak saptanmıştır. Bu durum Kwai ve arkadaşlarının yaptığ1 çalışmada daha kötü prognostik özelliklere sahip olmasından kaynaklabileceği gibi bizim çalışmamızda ki hasta sayısının az olması ile de ilişkili olabileceğini düşündürmektedir.

Gerçek yaşam deneyimlerini içeren diğer bir büyük çalışma Japonya da Tomoki Nakamura ve arkadaşları tarafindan yapılmıştır. Çalışma 156 hasta ile yapılmış olup medyan yaş 53.8 olarak bulunmuştur. Çalışmada 88 yaşında hasta mevcut olup hastaların üçte bire yakını 60 yaş üstündedir. 22 hasta yetmiş yaş üstü olup öncesinde kemoterapi tedavisi almamışlardır. Çalışmada PFS 15.4 hafta, OS ise 11.2 ay olarak saptanmıştır. Çalışmamızda 65 yaş üstü hastalar değerlendirilmiş olup medyan genel sağkalım 12 ay olarak saptanmıştır. Bu çalışma da 11 hastada pnomotoraks saptanmış olup 2 hastada grade 4 pnomotoraks gelişmiştir. Çalışma incelendiğinde metastaz sıklığı özellikle de akciğer metastaz varlığı göze çarpmaktadır. Yine çalışmada 16 hasta trombositopeni görülmüş olup 5 hastada grade 3-4 düzeyindedir ${ }^{20}$. Çalışmamız ile karşılaştırıldığında yan etki oranları daha sık ve ciddi düzeyde gözlenmiștir. $\mathrm{Bu}$ durum 22 hastanın yetmiş yaş üstü olup öncesinde kemoterapi tedavisi için uygun renal ve kardiyak fonksiyon açısından uygun olmayan kırılgan hastalar olmasından kaynaklanabilir. Bu çalışma ile kıyaslandığında yan etki oranlarımızın daha az olduğu görülmektedir. $\mathrm{Bu}$ durum çalışmamızın daha az hasta sayılı ve retrospektif küçük bir çalışma özelliğinden kaynaklanmış olabilir.
Böbrek ve yumuşak doku ve kanserlerinde yapılan çalışmalarda pazopanıb $800 \mathrm{mg}$ dozunun yan etki ve güvenirliği incelenmiş olup hastalarda çoğunlukla diyare el ayak sendromu, bulantı, yorgunluk ve transaminaz yüksekliği saptanmıştır. Çalışmamızda sıklıkla diyare el ayak sendromu, iştahsızlık ve bulantı şikayetleri gözlenmiştir. Hematolojik toksisiteler daha az oranda gözlemlenmiştir. Tedavi ilişkili febril nötropeni ve tedavi ilişkili ölüm gözlenmemiştir. Diyare gelişen 1 hastada ve karaciğer enzim yüksekliği olan 1 hastada tedaviye ara verilmiş olup şikayetler düzelince tedaviye pazopanib $600 \mathrm{mg}$ dozundan başlanılmıştır. Tedavi ilişkili ölüm ya da febril nötropeni gözlenmemiştir.

Sonuç olarak, çalışmamızda pazopanib tedavisi ile olguların yanıt oranı, ortalama sağ kalım süresi ve PFS süresi literatürdeki sonuçlara yakındır. Grade 3 veya 4 toksisite sıklığını arttırmamış ve iyi tolere edilmiştir.

\section{Kaynaklar}

1. Clark MA, Fisher C, Judson I, et al. Soft-tissue sarcomas in adults. N Engl J Med 2005;353:701-11.

2. Siegel R, Naishadham D, Jemal A. Cancer statistics, 2012. CA Cancer J Clin 2012;62(1):10-29.

3. Fletcher CD HP, Mertens F, Bridge J. WHO Classification of Tumours of Soft Tissue and Bone. 4th ed. Lyon, France: IARC Press; 2013.

4. Zager GK, Ballo MT, Pesters PW, et al. Prognostic factors for patients with localized soft-tissue sarcoma treated with conservation surgery and radiation therapy; an analysis of 1225 patients. Cancer 2003;97:2530-43.

5. Le Cesne A, Blay JY, Judson I, et al. Phase II study of ET-743 in advanced soft tissue sarcomas: a European Organisation for the Research and Treatment of Cancer (EORTC) soft tissue and bone sarcoma group trial. J Clin Oncol 2005; 23: 576-84.

6. Casali PG, Blay JY, ESMO/CONTICANET/EUROBONET Consensus Panel of Experts. Soft tissue sarcomas: ESMO clinical practice guidelines for diagnosis, treatment and follow-up. Ann Oncol 2010; 5 (suppl): 198-203.

7. Judson I, Verweij J, Gelderblom H, Hartmann JT, Schoffski P, Blay JY, et al. Doxorubicin alone versus intensified doxorubicin plus ifosfamide for first-line treatment of advanced or metastatic soft-tissue sarcoma: a randomised controlled phase 3 trial. Lancet Oncol 2014;15(4):415-23.

8. Maki RG, Wathen JK, Pater SR, et al. Randomised phase 2 study of gemcitabine and docetaxel compared with gemcitabine alone in patients with metastatic soft tissue sarcomas: results of Sarcoma Alliance for Research Trough Collaboration Study 002. J Clin Oncol 2007; 25: 2755-63.

9. Maki RG. Gemcitabine and docetaxel in metastatic sarcoma: past, present and future. Oncologist 2007; 12: 999-1006

10. 10.Schutz FA, Choueiri TK, Sternberg CN. Pazopanib: clinical development of a potent anti-angiogenic drug. Crit Rev Oncol Hematol 2011; 77: 163-71.

11. Sleijfer S, van der Graaf WT, Blay JY. Angiogenesis inhibition in non-GIST soft tissue sarcomas. Oncologist 2008; 13: 1193200.

12. DuBois S, Demetri G. Markers of angiogenesis and clinical features in patients with sarcoma. Cancer 2007; 109: 813-19. 


\section{E. Çubukçu, ark.}

13. Sleijfer S, Ray-Coquard I, Papai Z, et al. Pazopanib, a multikinase angiogenesis inhibitor, in patients with relapsed or refractory advanced soft tissue sarcoma: a phase II study from the European organisation for research and treatment of cancer-soft tissue and bone sarcoma group (EORTC study 62043). J Clin Oncol 2009; 27: 3126-32.

14. Scurr M. Histology driven chemotherapy in soft tissue sarcomas. Cur Treat Opt Oncol 2011; 12: 32-45.

15. Verweij J, Casali PG, Zalcberg J, et al. Progression-free survival in gastrointestinal stromal tumours with high-dose imatinib:randomised trial. Lancet 2004; 364: 1127-34.

16. George S, Merriam P, Maki RG, et al. Multicenter phase II trial of sunitinib in the treatment of nongastrointestinal stromal tumor sarcomas. J Clin Oncol 2009; 27: 3154-60

17. Hirata T, Yonemori K, Ando M, et al. Efficacy of taxane regimens in patients with metastatic angiosarcoma. Eur J Dermatol. 2011;21(4):539-45.
18. Italiano A, Cioffi A, Penel N, et al. Comparison of doxorubicin and weekly paclitaxel efficacy in metastatic angiosarcomas. Cancer. 2012;118(13):3330-6.

19. van der Graaf WT, Blay JY, Chawla SP, et al . EORTC Soft Tissue and Bone Sarcoma Group; PALETTE study group. Pazopanib for metastatic soft-tissue sarcoma (PALETTE): a randomised, double-blind, placebo-controlled phase 3 trial. Lancet 2012;19;379(9829):1879-86.

20. Nakamura T, Matsumine A, Kawai A, et al. The clinical outcome of pazopanib treatment in Japanese patients with relapsed soft tissue sarcoma: A Japanese Musculoskeletal Oncology Group (JMOG) study. Cancer. 2016;1;122(9):1408-16.

21. Sahin B. Yumuşak doku sarkomlarında kemoterapi. Türk Onkoloji Dergisi 2015;30(1):62-8. 